\title{
AOR
}

Selected Papers of \#AolR2019:

The $20^{\text {th }}$ Annual Conference of the Association of Internet Researchers Brisbane, Australia / 2-5 October 2019

\section{RELIEF FROM COMMUNICATION: PARENTAL SURVEILLANCE TECHNOLOGIES, TRUST AND CARE}

\author{
Maja Sonne Damkaer \\ Center for Surveillance Studies, Aarhus University \\ Clare Southerton \\ Vitalities Lab, University of New South Wales \\ Anders Albrechtslund \\ Center for Surveillance Studies, Aarhus University
}

\section{Introduction}

The everyday adoption of digital technologies such as mobile phones and social media has had transformative effects on interactions within the family (Clark, 2013), as families become increasingly dependent on their capacities for coordinating day-to-day activities and maintaining intimate relationships (Licoppe, 2004; Ling, 2014). Concurrently, these technologies enable new forms of surveillance, allowing parents to observe their children's movements and interactions remotely, eg. via GPS-apps (Marx \& Steeves, 2010), as well as lateral forms of surveillance embedded in social media practices like 'Facebook stalking' (Albrechtslund, 2013). This paper explores how the surveillant capacities of communication technologies are involved in shaping relations of trust in the family, drawing on empirical data from in-depth interviews with adolescents at two schools and 17 Danish families conducted during 2017. Despite surveillance often being represented as a practice which undermines trust (Mayer, 2003; Neyland, 2006; Rooney, 2010), our findings suggest that the relationship between trust and surveillance, for the families in our study, was far less straightforward. Surveillance was an important part of care practices for parents and, in some instances, tracking technologies were able to offer a kind of 'relief' from social pressures to remain in contact. This paper explores the perceptions of parents and adolescents regarding using communication technologies for surveillance, to examine the nuanced constitution of trust occurring.

\section{Case Study: Communication Technologies in Danish Families}

This study is part of a Danish research project that explores perceptions and experiences of everyday surveillance practices in family life. The project aims to

Suggested Citation (APA): Damkaer, MS, Southerton, C, Albrechtslund, A. (2019, October 2-5). Relief from Communication: Parental Surveillance Technologies, Trust and Care. Paper presented at AolR 2019: The $20^{\text {th }}$ Annual Conference of the Association of Internet Researchers. Brisbane, Australia: AoIR. Retrieved from http://spir.aoir.org. 
understand changing family relations as digital technologies become deeply embedded in many social rituals. Denmark is an affluent nation in the Global North with a strong uptake of domestic digital technologies. $93 \%$ of Danish families have access to a computer with internet access, and $88 \%$ of households have at least one smartphone (Tassy, Nielsen, \& Jakobsen, 2018). Scandinavian parenting, in general, is oriented towards democratic ideals, conversation and trust (Forsberg, 2009; Miklikowska \& Hurme, 2011). Certainly, Danish parents tracking children without their knowledge is not the norm. To understand both the perceptions of parents and young people, who experience these technologies differently, the project draws on two data sets comprised of 17 semi-structured in-depth interviews with families with children living at home, and 50 interviews conducted with adolescents (aged 14-17) at two Danish schools.

\section{Affording surveillance}

To understand the complex relationship between trust and privacy, we explore the interconnection between parenting, digital communication technologies and surveillance. Surveillance is an integrated part of parenting, as children need supervision until they come of age. The surveillant capacities of many of the digital technologies integrated into family life interact with relations of trust both directly, as a result of surveillant practices, and indirectly, through the perception of these surveillant capacities. We draw on the theory of affordances (Gibson, 1986) to conceptualise the capacities of these technologies as well as the perception of these capacities by the parents and adolescents in our study. Communication and media scholars have adopted the term both to emphasise the way that technologies enable actions as well as constrain and discourage others, both through their materiality and users perceptions (Hutchby, 2014; Schrock, 2015).

Parents and children mobilise the surveillant affordances of communication technologies both to establish trust and to provide relief from social pressures to remain in constant contact. On the basis of our analysis, we present compelling evidence that:

1) Tracking of children without their consent were in general perceived as a violation of their privacy and an unacceptable breach of trust (unless the child requires special assistance); 2) both parents and adolescents perceived parental surveillance by means of communication technologies (e.g. calls and texts) as a practice of care, as this rested on ideals of dialogue and trust; and 3) the families that had adopted tracking apps used them for mutual monitoring, as all family members were visible to each other, but surprisingly, their main motive was not efficient surveillance: It was 'communication relief' from a lot of 'disturbing' micro-coordination and 'checking up on each other's whereabouts'.

\section{Conclusion}

This paper examines the ways in which parents and children perceive and navigate the surveillant capacities of these everyday technologies, and the ways in which trust is both established and undermined. It is perhaps paradoxical that the Danish families in our study use communication tools for parental surveillance and tracking technologies for 'relief' from the pressure of constant communication. It is important to understand the way that the perception of the affordance of these technologies has influence, sometimes as much as the actualisation of that affordance. It is necessary also to note that Denmark is known for having high levels of social trust (Sønderskov \& Dinesen, 
2014), as well as a family and parenting culture that rests on 'democratic ideals', dialogue-based child rearing focusing on mutual trust and children's autonomy (Forsberg, 2009; Miklikowska \& Hurme, 2011). These characteristics no doubt influence the ways surveillance capacities are engaged with. Finally, though new technologies do introduce new capacities, there are continuities with existing family trust dynamics and we contend that child rearing necessarily involves a balancing of care and surveillance, freedom and control.

\section{References}

Albrechtslund, A. (2013). New Media and Changing Perceptions of Surveillance. In J. Hartley, J. Burgess, \& A. Bruns (Eds.), A Companion to New Media Dynamics (Vol. 13, pp. 309-321). Oxford: WileyBlackwell.

Forsberg, L. (2009). Involved Parenthood: Everyday Lives of Swedish Middle-Class Families (PhD). Linköping University. Retrieved from http://www.divaportal.org/smash/get/diva2:221242/FULLTEXT02.pdf

Gibson, J. J. (1986). The Ecological Approach to Visual Perception. New York, NY: Psychology Press. Hutchby, I. (2014). Communicative affordances and participation frameworks in mediated interaction. Journal of Pragmatics, 72, 86-89.

Licoppe, C. (2004). "Connected" presence: the emergence of a new repertoire for managing social relationships in a changing communication technoscape. Environment and Planning D: Society and Space, 22(1), 135-156.

Ling, R. (2014). Theorizing Mobile Communication in the Intimate Sphere. In G. Goggin \& L. Hjorth (Eds.), The Routledge Companion to Mobile Media (pp. 32-41). New York: Routledge.

Marx, G., \& Steeves, V. (2010). From the Beginning: Children as Subjects and Agents of Surveillance. Surveillance \& Society, 7(3/4), 192-230.

Mayer, R. N. (2003). Technology, Families, and Privacy: Can We Know Too Much About Our Loved Ones? Journal of Consumer Policy, 26(4), 419-439.

Miklikowska, M., \& Hurme, H. (2011). Democracy begins at home: Democratic parenting and adolescents' support for democratic values. The European Journal of Developmental Psychology, 8(5), 541-557.

Neyland, D. (2006). Privacy, Surveillance and Public Trust. Basingstoke: Palgrave Macmillan.

Rooney, T. (2010). Trusting Children: How do surveillance technologies alter a child's experience of trust, risk and responsibility? Surveillance \& Society, 7(3/4), 344-355. 
Schrock, A. R. (2015). Communicative Affordances of Mobile Media: Portability, Availability, Locatability, and Multimediality. International Journal of Communication Systems, 9, 1229-1246.

Sønderskov, K. M., \& Dinesen, P. T. (2014). Danish Exceptionalism: Explaining the Unique Increase in Social Trust Over the Past 30 Years. European Sociological Review, 30(6), 782-795.

Tassy, A., Nielsen, M. B., \& Jakobsen, D. T. (2018). It-anvendelse i befolkningen 2018. Danmarks Statistik. Retrieved from http://www.dst.dk/Publ/ltBefolkning 